4. Доповнена реальність до графічних робіт із колекції музею «4-й Блок». кер. Опалєв М. Л. URL: https://www.youtube.com/watch?v= 7CQzCHsg_SM (дата звернення 20.11.2020)

5. Augmenting Fine Art with SFMOMA (The San Francisco Museum of Modern Art). Special exhibition, "Rene Magritte: The Fifth Season,”. 2018. URL: https://www.youtube.com/watch?v=Oih_StvytQs (дата звернення 17.11.2020)

DOI https://doi.org/10.30525/978-9934-26-004-9-112

\title{
ДИТЯЧА ТВОРЧІСТЬ У ДИЗАЙНІ УКРАЇНСЬКОЇ КНИГИ
}

\author{
Пшінка Н. М. \\ аспірант, викладач кафедри рисунка та живопису \\ Київського національного університету технологій та дизайну \\ Гула Є. П. \\ професор, \\ завідувач кафедри рисунка та живопису \\ Київського наиіонального університету технологій та дизайну \\ м. Київ, Украӥна
}

Дитячі малюнки у книжкових виданнях минулого століття використовувалися зрідка, оскільки юні митці здатні відтворити власні емоції, свій внутрішній світ, але від них не можна очікувати цілісного бачення архітектоніки книги як єдиного організму, проєктування стрункого, продуманого макету тощо, а тому необхідним є залучення професійного дизайнера, який, втім, також був обмежений технічними можливостями тогочасної поліграфії. I лише із появою і розвитком цифрових комп'ютерних технологій стало можливим ширше залучення дітей до ілюстрування книжок.

Вже $з$ 1990-х у Національному видавництві дитячої літератури «Веселка» розпочинається активний пошук нових форм подачі візуального матеріалу. Видавництво організовує конкурси, підтримує зв'язок із дитячими студіями і школами мистецтв, започатковує серію «Ластовенятко», де й друкуються юні таланти. Для нашого дослідження цікаві насамперед ті серійні видання, де i авторами текстів, i художниками-ілюстраторами виступають діти $[1,2,3,4]$. 
Цікаво проаналізувати i тематику дитячих малюнків. Якщо у названих вище виданнях сюжети цілком традиційні: яскраве і радісне дитяче довкілля, сім'я, розваги, краса природи, казковий, фантастичний світ, то з 2014 року, з початком воєнного конфлікту на сході України, мільйони дітей взялися творити яскраві мальовані послання для захисників Батьківщини - українських військових зі словами підтримки й добрими побажаннями [5, с. 5-6].

Промовиста світлина воїна 3 дитячими малюнком у руках вдало використана як своєрідний епіграф до книжки оповідань Л. Загоровської «На їхніх маленьких плечах...» про дітей, «які вже знають (хто з власного досвіду, хто 3 розповідей), що таке війна, страждання, самотність. Знають і розуміють серцем, що нині, коли на рідній землі йде війна, нікому не можна стояти осторонь цих подій, бути байдужим» [5, с. 109]. Виконати ілюстрації до оповідань видавництво «Веселка» запропонувало студентам Київської дитячої Академії мистецтв, віком від 8 до 19 років, тож і рівень професіоналізму робіт різний, але їх вирізняє емоційне наповнення, глибина переживань, розкутість композицій, а разом - синергія вербального і візуального ряду (рис. 1 б).

Роботу дизайнера характеризує фахівець 3 дитячої літератури Н. Марченко: «Дуже важливо, що «Веселці» вдалося створити видання, котре найбільш повно відповідає суті закладеного в тексти автором гуманістичного посилу. Білосніжна обкладинка (рис. 1 a) зі «світлиною» зібраних Оксаною Здор із «облич», намальованих юними ілюстраторами «героїв», як і нестандартний розмір книжки відразу розставляють потрібні акценти у сприйнятті юного читача» [6].

Таке використання в дизайні книги яскравих дитячих малюнків сприяло глибшому розкриттю складної для юних читачів теми війни, збереженню у них оптимістичного сприйняття дійсності, забезпечило важливу соціокомунікативну функцію дитячої книги.

Про те, що юним художникам до снаги творити візуальний образ складної вербальної інформації, передаючи іï глибинні сенси: питання морально-етичного вибору, проблеми людських відносин, психологію особистості та соціуму, свідчить і книга роздумів-настанов «Про гріхи і чесноти» Блаженнішого Любомира Гузара - патріарха-предстоятеля Української Греко-Католицької Церкви (видавництво «Фоліо») [7] 3 дитячими ілюстраціями. Наївні і щирі, позбавлені холодного офіціозу малюнки швидше прокладають шлях до юних сердець (рис. 2 a, б). Спонукає дизайнерів залучати дитячі малюнки і потреба протистояти нівелюванню індивідуального і національного стилю в оформленні книжок. «Домінування глобалістичних ознак у дизайні сучасного 
дитячого видання засвідчили необхідність пошуків національної ідентифікації у проектуванні дитячої книги України» [8, с. 36].

Видавництво «Веселка», продовжує плідну співпрацю 3 юними талантами, ініціювало і випустило в світ (за підтримки Українського культурного фонду і ГО «Вулик ідей») унікальний, перший в Україні інклюзивний проєкт типізованих видань - збірників-мультилінгвів народних пісень «Рідна колисанка», 2019 р. [9] і «Рідна колисанка-2», 2020 p. [10] (puc. 3, а, б, в).

Як зазначають фахівці, це видання «...втілило у собі синергію провідних імперативів нашого часу - інклюзивності, мультикультурності та мультимедійності. Водночас книжка стала чи не першою, де свідома державницька позиція реалізується шляхом глибоко особистісного співпереживання ідеї Єдності та Людяності «Українського світу», його відкритості та сердечності. Видання створене задля долучення дітей із інвалідністю через мистецтво до вивчення та поширення знань, котрі дають змогу усвідомити багатоманіття нашої країни, дізнатися про історію, мови, традиції та культуру народів, які 3 давніх часів проживають в Україні» [11]. Упродовж року у видавництві проводились арттерапевничні заняття для особливих дітей; вони слухали колискові пісні мовою різних народів у виконанні професійних співаків, роздивлялися національні костюми, знайомилися з культурою і побутом, а потім втілювали свої враження, своє «вживання» в кожну 3 культур через мистецтво, створюючи малюнки, аплікації з паперу, фетру, піску, круп, пластиліну та навіть із бульбашок і піни, ниткографії і плямографії. «Кращі роботи юних митців увійшли до книжок, надавши їм «щемкого, дитячого й водночас високо мистецького, символічного звучання» [11].

Завдяки успішній співпраці упорядника текстів та ілюстрацій Ірини Бойко, дизайнера і художника Оксани Здор вдалоя вирішити непросте завдання - закомпонувати на кожному розвороті книжки (рuc. 3 в) різнопланові текстові масиви (колискову мовою оригіналу, український переклад, «Словничок», дитячі малюнки, доповнені національним орнаментом та авторським зображенням дітей у відповідних національних костюмах), а також QR-коди та посилання на доступ до спеціального сайту 3 аудіоальбомом колискових, записаних професійними виконавцями у професійній студії. Вміщено також нотний додаток. Для людей із вадами зору підготовлено видання шрифтом Брайля. Автори проєкту так визначають його головну мету - через мистецтво сприяти соціалізації, інтернаціоналізації та самоідентифікації дітей 3 інвалідністю, а нормотипічним дітям дати уявлення про світ, в 
якому живуть їхні ровесники, організувати їхнє спілкування і взаємодію $[8$, c. 32].

У висновку зазначимо: українські видавництва сьогодні пропонують інноваційні підходи до дизайну книжок 3 використанням дитячої образотворчості, що потребує уваги дослідників.

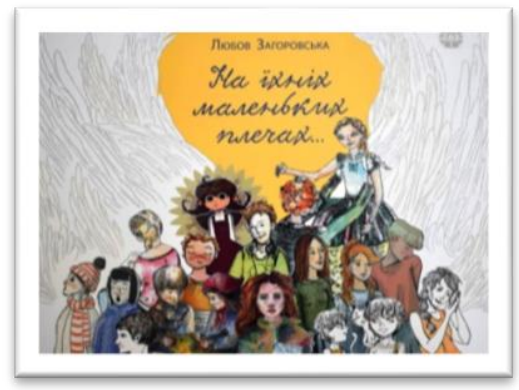

a

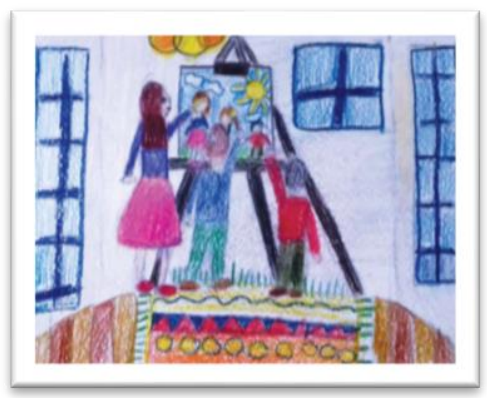

6

Рис. 1: а) Обкладинка. Дизайнер О. Здор.

б) Ілюстрація. Малювала Дарія Бубар, 8 років

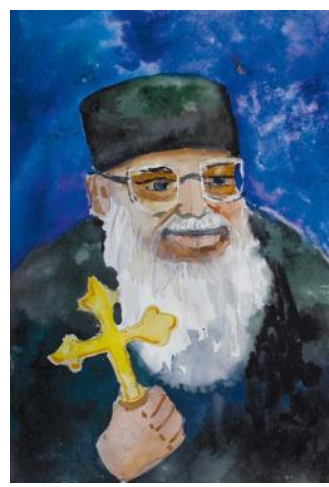

a

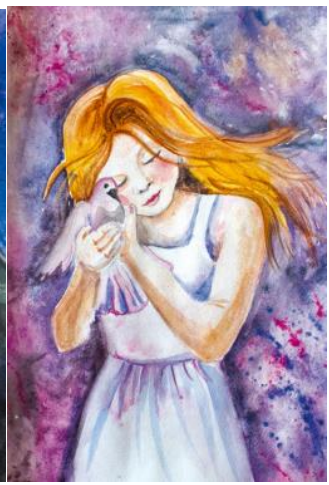

6

Рис. 2. Ілюстрації до книжки Л. Гузара «Про гріхи і чесноти» Малювала Ілона Шустер, 14 років: а) Любомир Гузар. б) Доброта 


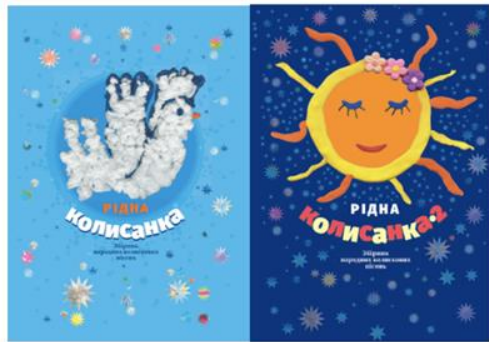

a

б

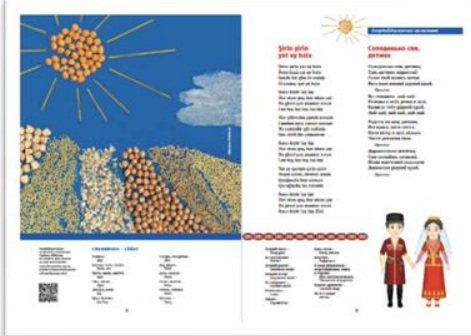

B

Рис. 3. Ілюстрації до книжок «Рідна колискова»:

а, б) Обкладинки. в) Композиція розвороту

\section{Література:}

1. Білоус Христина. Вертепна зірка. Київ : Веселка, 1992. 24 с.

2. Рута Оляна Рожеві птахи. Київ : Веселка, 1993. 32 с.

3. Луговик Марійка. Білий бегемотик. Київ : Веселка, 1995. 16 с.

4. Ластовенятко : вірші, оповідання, казки / упоряд. і передм. Надії Кир'ян. Київ : Веселка, 1995. 79 с.

5. Загоровська Л. М. На їхніх маленьких плечах... : оповідання : / передм. О. Білозір; іл. студентів Київської дитячої Академії мистецтв, обкл. О. Здор. Київ : Веселка, 2018. 110 с.

6. Марченко Наталя. Щиросердна книга всеперемагаючої Людяності [Електронний pecypc]. URL: http://www.chl.kiev.ua/key/Books/ ShowCategory/2 (дата звернення 20.11.2020).

7. Гузар Любомир. Про гріхи і чесноти. Харків : Фоліо, 2018. 141 с.

8. Єфімова М. П. Дизайн дитячої книги України: проєктно-художні принципи і засоби : дис. ... канд. мистецтвознавства : 17.00.07. Харків, 2015.

9. Рідна колисанка : зб. народ. колискових пісень (з нотним додатком і картою України) / упоряд. І. Бойко, К. Айріян; вступ О. Змієвської ; післямова М. Сніжної ; пер. укр. О. Москальця та ін.; худож. О. Здор ; упоряд. карти О. Бондаренка. Київ : Веселка, 2019. 31 с.

10. Рідна колисанка-2 : зб. народ. колискових пісень (з нотним додатком і картою України) / упоряд. I. Бойко, О. Бондаренка, М. Сніжної; передмова Н. Марченко; післямова Ю. Федорової; пер. укр. Н. Кир'ян та ін.; худож. О. Здор. Київ : Веселка, 2020. 31 с.

11. Марченко Наталя. Найбільше сили й свободи дарує розуміння Іншого [Електронний pecypc]. URL: http://www.chl.kiev.ua/key/ Books/ShowBook/649 (дата звернення 20.11.2020). 